Article

\title{
Transformation of Vanadium-Bearing Titanomagnetite Concentrate in Additive-Free Roasting and Alkaline-Pressure Leaching for Extracting Vanadium (V)
}

\author{
Haiyan Zheng ${ }^{1, * \mathbb{D}}$, Weiling Zhang ${ }^{2, *}$, Yongchun Guo ${ }^{1}$, Qiangjian Gao ${ }^{1}$ and Fengman Shen ${ }^{1}$ \\ 1 School of Metallurgy, Northeastern University, Shenyang 110819, China; 1771163@stu.neu.edu.cn (Y.G.); \\ gaoqj@smm.neu.edu.cn (Q.G.); shenfm@mail.neu.edu.cn (F.S.) \\ 2 Baosteel Zhanjiang Iron \& Steel Co., Ltd., Zhanjiang 524072, China \\ * Correspondence: zhenghy@smm.neu.edu.cn (H.Z.); 684880@baosteel.com (W.Z.); \\ Tel.: +86-24-8369-1266 (H.Z.); +86-759-352-8317 (W.Z.)
}

Received: 24 February 2019; Accepted: 21 March 2019; Published: 26 March 2019

\begin{abstract}
With a view to satisfying the requirements of environmental protest and efficient usage of resources, a novel process for efficiently extracting vanadium $(\mathrm{V})$, titanium $(\mathrm{Ti})$, and iron $(\mathrm{Fe})$ from vanadium-bearing titanomagnetite concentrate was developed. In the new process, vanadium is pre-extracted by additive-free roasting under the air atmosphere and alkaline leaching technologies. In this paper, transformation of vanadium-bearing titanomagnetite concentrate in the roasting is investigated based on thermodynamic analyses and experimental discussion. Thermodynamic analyses show that oxidation of $\mathrm{V}(\mathrm{III})$ into $\mathrm{V}(\mathrm{V})$ would happen in the roasting experiment over the range of $327-1327^{\circ} \mathrm{C}$ and vanadium-iron spinel phase $\left(\mathrm{FeV}_{2} \mathrm{O}_{4}\right)$ can be oxidized more easily than magnetite $\left(\mathrm{Fe}_{3} \mathrm{O}_{4}\right)$ when the temperature is higher than $861^{\circ} \mathrm{C}$. Experimental results show that some compounds $\left(\mathrm{V}_{2} \mathrm{O}_{5}, \mathrm{Fe}_{2} \mathrm{Al}_{4} \mathrm{Si}_{5} \mathrm{O}_{18}\right.$, and $\left.\mathrm{Fe}_{2} \mathrm{SiO}_{4}\right)$ with low melting temperature were obtained by solid reactions at low temperature and melted as a binding phase at elevated temperature. Liquids were generated due to some chemical reactions or phase transformation reaction $\left(\mathrm{Fe}_{2} \mathrm{~V}_{2} \mathrm{O}_{4}(\mathrm{~s}) \rightarrow\right.$ $\mathrm{Fe}_{2} \mathrm{O}_{3}(\mathrm{~s})+$ liquid) at elevated temperature. Main phases of $\mathrm{Fe}_{2} \mathrm{O}_{3}$ and $\mathrm{Fe}_{2} \mathrm{TiO}_{5}$ are connected and sintered with the binding phases of the compounds with low melting temperature or the mixtures with low liquidus temperature. In addition, higher roasting temperature leads to higher vanadium leaching efficiency over the range of $800-1200{ }^{\circ} \mathrm{C}$. However, over-burning would happen at $1250^{\circ} \mathrm{C}$, some of vanadium oxide was wrapped by silicate network, and the conversion of $\mathrm{V}(\mathrm{III})$ into $\mathrm{V}(\mathrm{V})$ was prevented from occurring. Therefore, the vanadium leaching efficiency decreased from $59.1 \%$ $\left(T_{\text {roa. }}=1200{ }^{\circ} \mathrm{C}\right)$ to $57 \%\left(T_{\text {roa. }}=1250^{\circ} \mathrm{C}\right)$.
\end{abstract}

Keywords: vanadium-bearing titanomagnetite concentrate; additive-free roasting; vanadium extraction; transformation mechanism; silicate network

\section{Introduction}

Vanadium-bearing titanomagnetite is a very important mineral resource of vanadium, titanium and iron. Currently, the major process for smelting vanadium-bearing titanomagnetite involves firstly extracting iron and then extracting vanadium of slag by sodium salt roasting and water leaching technologies [1-8], which causes serious environmental pollution (especially hazardous gases, such as $\mathrm{HCl}, \mathrm{SO}_{2}$, or $\mathrm{Cl}_{2}$ ) and low recovery ratio of vanadium (total recovery ratio $<45 \%$ ) and titanium (total recovery ratio $<10 \%$ ) [8]. In addition, soluble vanadium (V(IV) and $\mathrm{V}(\mathrm{V})$ ) substances are toxic substances and vanadium-rich resources are a potential toxic solid because deleterious health effects 
induced by inorganic vanadium compounds have been reported $[9,10]$. Therefore, more attention has been drawn to comprehensive and efficient extraction of valuable elements $(\mathrm{V}$, $\mathrm{Ti}$, and $\mathrm{Fe})$ from titanomagnetite deposits with a new environmentally-friendly method.

Regarding the extraction of vanadium from vanadium-bearing resources (such as vanadium-bearing titanomagnetite, vanadium-rich slag, stone coal) many efforts have been made by researchers [11-27]. A calcium roasting method followed by acid or alkaline leaching was an alternative process to extract vanadium with the purpose of avoiding harmful gas generation (such as $\mathrm{HCl}, \mathrm{SO}_{2}, \mathrm{or}_{2}$ ), but it always results in low quality vanadium products $\left(\mathrm{V}_{2} \mathrm{O}_{5} 94 \%<98 \%\right.$ of high quality) and high acid leaching [11]. Direct acid leaching method without roasting attracted more attention as it has no exhaust gas generation, but it also has the problems of low leaching efficiency $(74 \%)$ of vanadium and usage of excess leaching agent [12].

Based on the abovementioned background, a novel process for extracting vanadium, titanium, and iron from vanadium-bearing titanomagnetite concentrate was developed. The proposed new process involves three parts: (1) pre-extracting vanadium from vanadium-bearing resources by additive-free roasting under the air atmosphere and alkaline-pressure leaching technologies; (2) reducing the vanadium-free pellets after roasting for producing direct reduction iron (DRI); (3) separating the DRI from titano-rich slag, which can be used as the alternative of raw material for the production of titanium oxide or titanium smelting process. The advantages of this process are that it is possible to utilize vanadium-bearing resources rationally and recover vanadium, iron, and titanium efficiently; moreover, it is a simple, relatively fast, semi-continuous, easy to scale-up, and environmental-friendly process because it has no additive usage compared with the traditional process. Thus, it is beneficial to achieving sustainable development. This paper focuses on discussing the transformation of vanadium-bearing titanomagnetite concentrate in the roasting process.

\section{Thermodynamic Criteria for Roasting}

Usually, $\mathrm{V}$ as the form of $\mathrm{V}$ (III) solutes into iron oxide in the form of isomorphism instead of Fe(III) in $\mathrm{Fe}_{3} \mathrm{O}_{4}$ because the radius of $\mathrm{V}$ (III) is close to the radius of $\mathrm{Fe}(\mathrm{III})\left(R_{\mathrm{V}(\mathrm{III})}=0.65 \AA \approx R_{\mathrm{Fe}(\mathrm{III})}=0.67 \AA\right)$, vanadium in the ore or slag is therefore considered as the form of vanadium-iron spinel $\left(\mathrm{FeV}_{2} \mathrm{O}_{4}\right.$ or $\left.\mathrm{FeO} \cdot \mathrm{V}_{2} \mathrm{O}_{3}\right)[28,29]$. Furthermore, it is noted that the suboxide of vanadium (V(III), $\mathrm{V}(\mathrm{IV})$ ) is hardly soluble into acid, neutral or alkaline solutions [30], therefore, it is required to change the suboxide $(\mathrm{V}(\mathrm{III}), \mathrm{V}(\mathrm{IV}))$ into $\mathrm{V}(\mathrm{V})$, which is soluble in alkaline solutions, in order to extract vanadium from the ore. Therefore, the reactions in the roasting, which are essential to vanadium extraction, are discussed from thermodynamic viewpoints.

While discussing the thermodynamic properties of the Fe-Ti-V-O system at elevated temperatures, it is essential to consider the existence of complex oxides, such as $\mathrm{FeTi}_{\mathrm{x}} \mathrm{O}_{\mathrm{y}}$, and $\mathrm{FeV}_{\mathrm{x}} \mathrm{O}_{\mathrm{y}}$. The Gibbs energy changes of the following reactions are not large compared to those of the redox reactions in the related systems as shown in Figure 1 [31].

$$
\begin{gathered}
\mathrm{FeO}(\mathrm{s})+\mathrm{TiO}_{2}(\mathrm{~s})=\mathrm{FeTiO}_{3}(\mathrm{~s}) \\
\Delta G^{\circ}{ }_{\mathrm{r}}=-10.987 \mathrm{~kJ} / \mathrm{mol} \text { at } 1100 \mathrm{~K} \\
\mathrm{FeO}(\mathrm{s})+\mathrm{V}_{2} \mathrm{O}_{3}(\mathrm{~s})=\mathrm{FeV}_{2} \mathrm{O}_{4}(\mathrm{~s}) \\
\Delta G_{\mathrm{r}}^{\circ}=-13.204 \mathrm{~kJ} / \mathrm{mol} \text { at } 1100 \mathrm{~K}
\end{gathered}
$$

Furthermore, when the activity of $\mathrm{FeO}_{x}$ decreases due to the formation of complex oxides, the activity of $\mathrm{TiO}_{2}$ and $\mathrm{V}_{2} \mathrm{O}_{3}$ decreases by almost the same magnitude. In order to facilitate a simple discussion, $\mathrm{FeTi}_{\mathrm{x}} \mathrm{O}_{\mathrm{y}}$ and $\mathrm{FeV}_{\mathrm{x}} \mathrm{O}_{\mathrm{y}}$ are therefore considered to be the mixtures of $\mathrm{TiO}_{\mathrm{x}}+\mathrm{FeO}_{\mathrm{x}}$ and $\mathrm{VO}_{\mathrm{x}}+\mathrm{FeO}_{\mathrm{x}}$ respectively and vice versa. In Figure 1, $\mathrm{Fe}_{2} \mathrm{TiO}_{5}\left(\mathrm{Fe}_{2} \mathrm{O}_{3} \cdot \mathrm{TiO}_{2}\right)$ and $\mathrm{Fe}_{2} \mathrm{~V}_{2} \mathrm{O}_{8}\left(\mathrm{Fe}_{2} \mathrm{O}_{3} \cdot \mathrm{V}_{2} \mathrm{O}_{5}\right)$ are considered to be the mixtures of $\mathrm{TiO}_{2}+\mathrm{Fe}_{2} \mathrm{O}_{3}$ and $\mathrm{V}_{2} \mathrm{O}_{5}+\mathrm{Fe}_{2} \mathrm{O}_{3}$ respectively.

Figure 1 shows the relationship between standard Gibbs free energy of some Reactions (3)-(8) [31,32] listed below and temperature. As shown in Figure $1, \Delta G^{\circ}$ of oxidation Reactions (3)-(8) [31,32] over 
the range of $327-1327^{\circ} \mathrm{C}(600-1600 \mathrm{~K})$ are lower than zero and the oxidation reactions are spontaneous from left to right. When the temperature is higher than $861^{\circ} \mathrm{C}\left(T_{\text {Cross }}=1134 \mathrm{~K}\right.$, the temperature at black cross point in Figure 1), vanadium-iron spinel phase $\left(\mathrm{FeV}_{2} \mathrm{O}_{4}\right)$ can be oxidized more easily than magnetite $\left(\mathrm{Fe}_{3} \mathrm{O}_{4}\right)$ from the view of thermodynamic analysis. Thus, the experiment temperature is set at $800{ }^{\circ} \mathrm{C}$ or higher in this study in order to ensure all the suboxide of vanadium (mainly $\mathrm{V}_{2} \mathrm{O}_{3}$ ) can be oxidized into $\mathrm{V}_{2} \mathrm{O}_{5}$, which can be dissolved easier than $\mathrm{V}_{2} \mathrm{O}_{3}$ into alkaline solution.

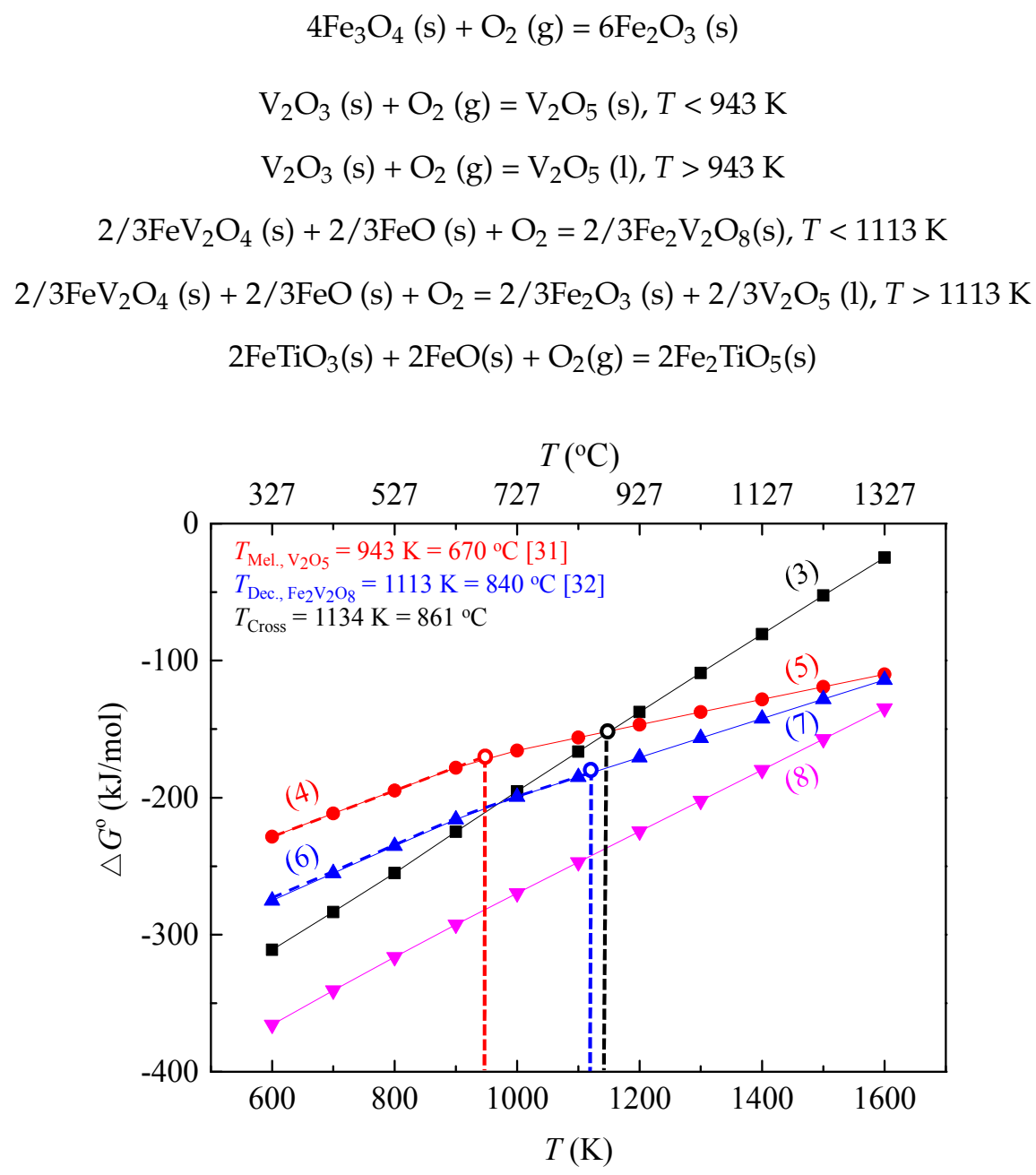

Figure 1. Standard Gibbs free energy diagram of some reactions. Reproduced with permission from [31], Copyright (c) 1995 VCH Verlagsgesellschaft mbH.

\section{Materials and Methods}

\subsection{Raw Materials}

Vanadium-bearing titanomaginetite concentrate used as the raw material in this study is provided from a steel factory of China and its composition by X-ray fluorescence spectrometry analysis (XRF, Rigaku ZSX Primus II) is shown in Table 1. As shown in Table 1, contents of vanadium and calcium in the ore are low. Low $\mathrm{CaO}$ is beneficial to the leaching of vanadium because calcium vanadate $\left(x \mathrm{CaO} \cdot \mathrm{V}_{2} \mathrm{O}_{5}, x=1,2,3\right)$ would be generated via the reaction of $\mathrm{CaO}$ with $\mathrm{V}_{2} \mathrm{O}_{5}$ and it is water-insoluble $[30,33]$ which leads to a reduction in vanadium extraction. 
Table 1. Composition of vanadium titanomagnetite concentrate used in this study $(\mathrm{XRF})$ *.

\begin{tabular}{cccccccccc}
\hline Composition & $\mathrm{Fe}_{2} \mathrm{O}_{3}$ & $\mathrm{TiO}_{2}$ & $\mathrm{Al}_{2} \mathrm{O}_{3}$ & $\mathrm{SiO}_{2}$ & $\mathrm{MgO}$ & $\mathrm{CaO}$ & $\mathrm{V}_{\mathbf{2}} \mathrm{O}_{5}$ & $\mathrm{MnO}$ & Sum \\
\hline Content (\%) & 72.55 & 12.68 & 4.66 & 3.82 & 3.26 & 0.96 & 0.75 & 0.64 & 99.51 \\
\hline
\end{tabular}

* Contents of $\mathrm{Fe}$ and $\mathrm{V}$ in the ore are determined as $\mathrm{Fe}_{2} \mathrm{O}_{3}$ and $\mathrm{V}_{2} \mathrm{O}_{5}$ respectively by XRF analysis. Contents of $\mathrm{V}$, $\mathrm{TFe}$, and $\mathrm{FeO}$ are $0.414 \%, 57.39 \%$, and $33.76 \%$ respectively by chemical analysis. Sodium hydrate $(\geq 96.0 \%$, AR) was used as leaching agent in this study.

\subsection{Experimental}

Vanadium-bearing titanomagnetite concentrate from the factory cannot be used directly because it is damp. As a result, the ore needs to be dried for a few hours. In a typical experiment, the ground ore $(-74 \mu \mathrm{m})$ without free water was subjected to oxidative roasting in air (partial pressure of oxygen is $0.021 \mathrm{MPa}(0.21 \mathrm{~atm})$ ) without additives in a muffle furnace over the range of $800-1250{ }^{\circ} \mathrm{C}$ for $2 \mathrm{~h}$. After roasting, the ore was cooled in the atmosphere and ground into the target particle size $(-74 \mu \mathrm{m})$ for leaching or related analyses. The leaching conditions are $250{ }^{\circ} \mathrm{C}$ for $4 \mathrm{~h}$ in a sealed reactor with high pressure (1.3 MPa) and stirring of $300 \mathrm{r} / \mathrm{min}, 3: 1$ of the ratio of liquor to solid, and $100 \mathrm{~g} / \mathrm{L} \mathrm{NaOH}$ as leaching agent. After leaching, the residues are separated from leach liquor with suction device and cleaned with distilled water for three times. Finally, the residues are weighed and subjected to analysis.

Related analyses used in this study are chemical analysis, X-ray fluorescence spectrometry analysis (XRF, Rigaku ZSX Primus II, Rigaku Corporation, Tokyo, Japan), X-ray diffraction (XRD, PANalytical X Pertpro, PANalytical B.V., Almelo, The Netherlands), scanning electron microscopy-energy dispersive spectroscopy analysis (SEM-EDS, Shimadzu SSX-550, Shimadzu Corporation, Tokyo Japan), and thermal gravimetry-differential scanning calorimetry analysis (TG-DSC, Netzsch STA449 F3, Netzsch Group, Selb, Germany).

\section{Results and Discussion}

\subsection{Mineral Analysis}

As shown in Figure 2, the phases in the ore are magnetite $\left(\mathrm{Fe}_{3} \mathrm{O}_{4}\right)$ and ilmenite $\left(\mathrm{FeO} \cdot \mathrm{TiO}_{2}\right)$, which agrees with the analysis in Table 2. Other compositions cannot be found in the XRD pattern due to their low contents. Figure 3a shows that there are three different regions (point 1: white region, point 2: light grey region, and point 3: grey region). It is found that the compositions by EDS analyses in the ore are iron and titanium oxides (points 1 and 2 in Figure 3a) as shown in Figure 3b,c, vanadium oxides associated with iron and titanium oxides (point 1 in Figure 3a) as shown in Figure 3a, and magnesium, aluminum, and silicon oxides (point 3 in Figure 3a) as shown in Figure 3d. The EDS results agree with XRF analysis in Table 2 and XRD analysis in Figure 2.

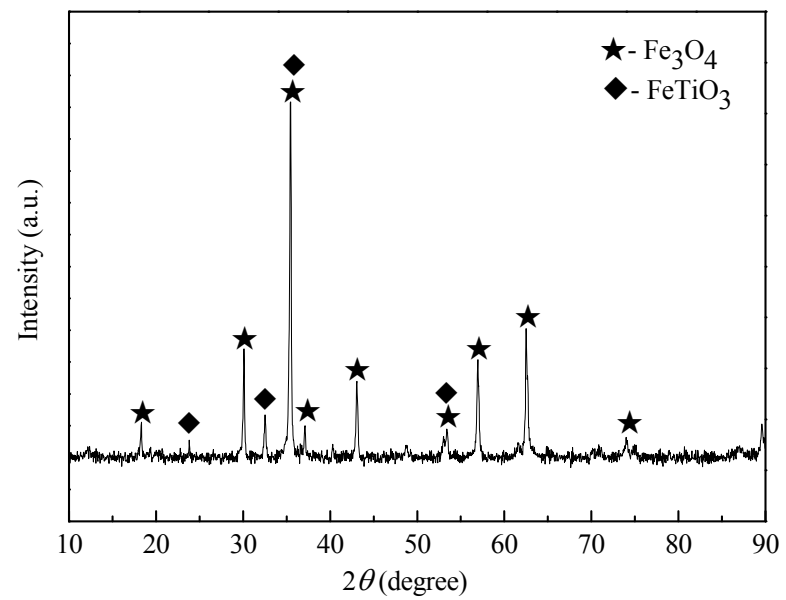

Figure 2. XRD pattern of vanadium-bearing titanomagnetite concentrate used in this study. 

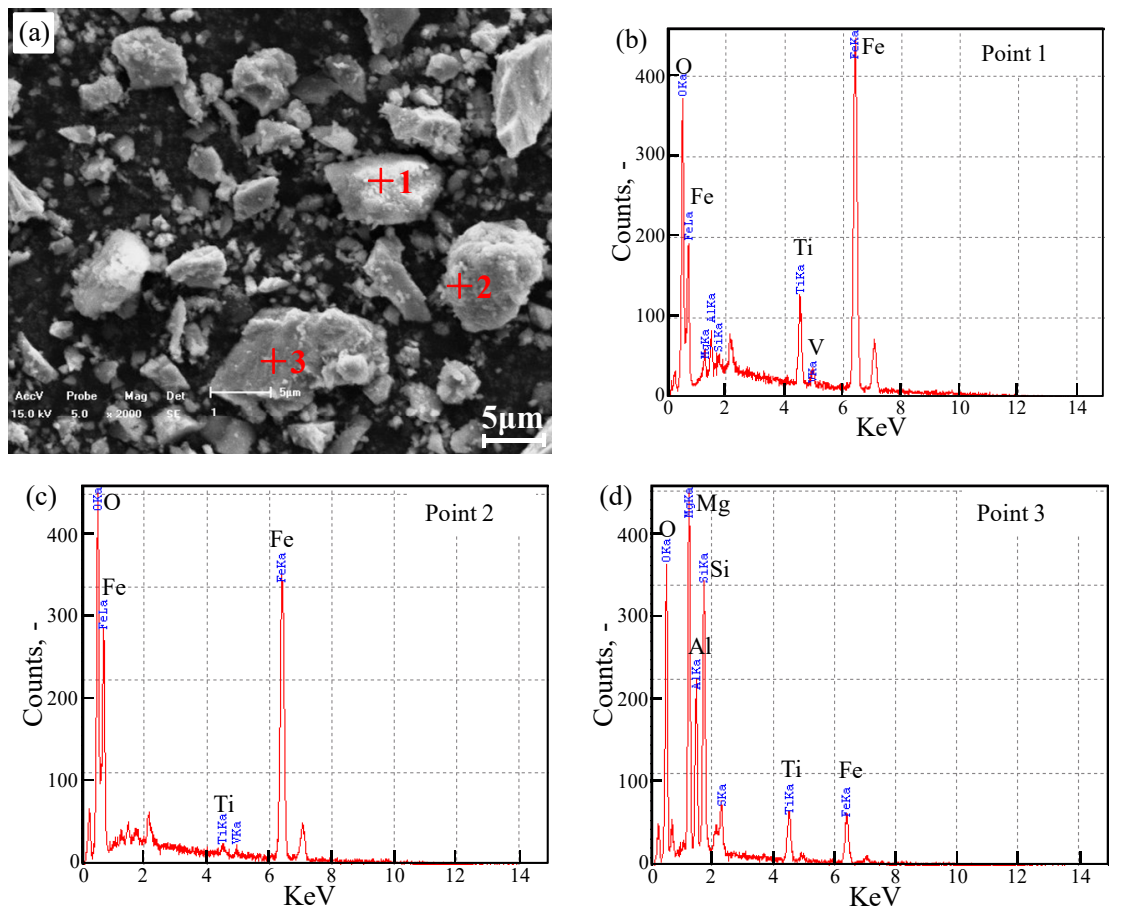

Figure 3. SEM micrograph and EDS of vanadium-bearing titanomagnetite concentrate: (a) SEM micrograph; (b) EDS of Point 1 in Figure 3a; (c) EDS of Point 2 in Figure 3a; (d) EDS of Point 3 in Figure 3a.

\subsection{TG-DSC Analysis}

The TG-DSC analysis for vanadium-bearing titanomagnetite was conducted in order to investigate the physicochemical behavior during the roasting process. Figure 4 is the TG-DSC analysis of vanadium-bearing titanomagnetite under the air atmosphere.

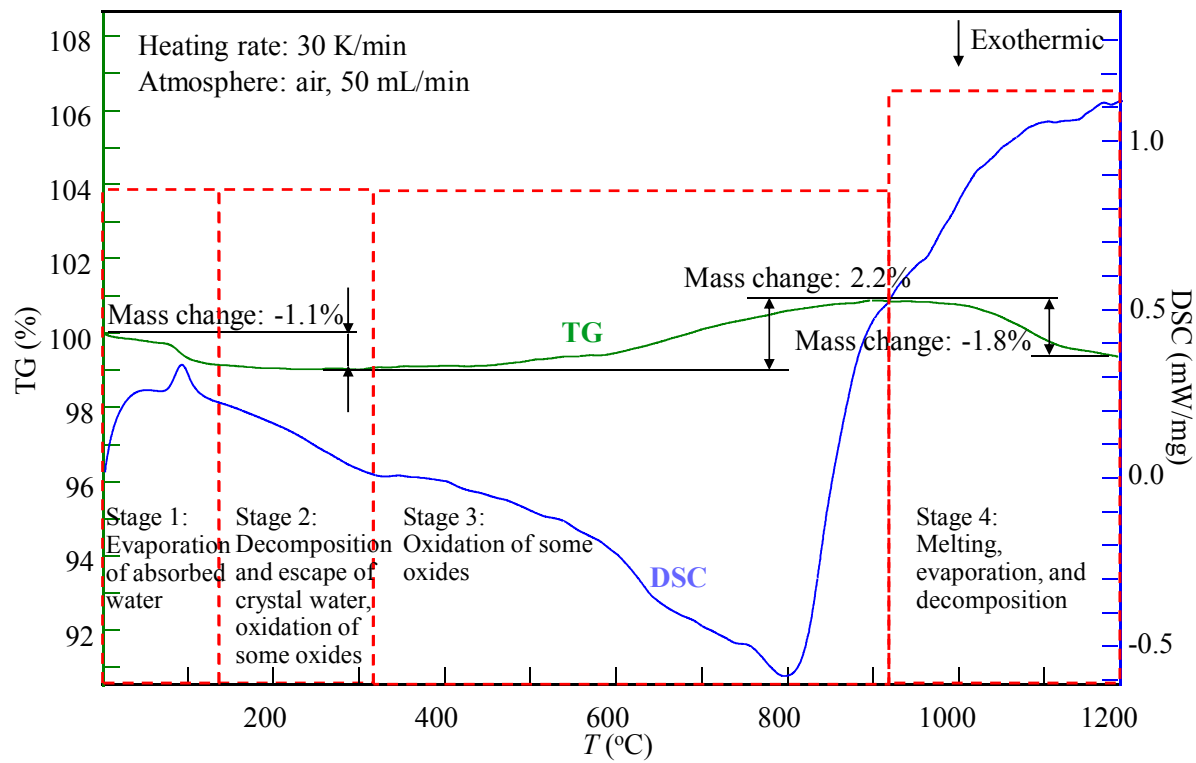

Figure 4. TG-DSC analysis of vanadium-bearing titanomagnetite concentrate.

There are two stages of weight loss (stage 1 and stage 4), one stage of no change in weight (stage 2), and one stage of weight increase (stage 3 ) as shown in Figure 4 . Weight change in TG is $-1.1 \%$ from room temperature to $140^{\circ} \mathrm{C}$. Corresponding to the stage 1 of TG, an endothermic peak in DSC appears 
and is caused by the evaporation of absorbed water (mass loss) in the ore. From $140{ }^{\circ} \mathrm{C}$ to $320^{\circ} \mathrm{C}$ (stage 2), escape of crystal water accompanying mass loss and endothermic process and the oxidation of some oxides accompanying mass increase and exothermic process happened. Therefore, TG-DSC shows no change in weight and endothermic process due to the coupling effect of evaporation of crystal water (mass loss) and the oxidation of some low valent oxides, such as the oxides of V(III), $\mathrm{Fe}(\mathrm{II}), \mathrm{Mn}(\mathrm{II})$, in the ore (mass increase). Weight change in TG is $+2.2 \%$ at the stage 3 from $320^{\circ} \mathrm{C}$ to $920^{\circ} \mathrm{C}$. There is an exothermic trough corresponding to the stage 3 , which is caused by the oxidation of suboxide, such as Fe(II) or V(III), in the ore. Weight change in TG is $-1.8 \%$ at the stage 4 from $920{ }^{\circ} \mathrm{C}$ to $1200^{\circ} \mathrm{C}$ and there is an endothermic peak corresponding to the stage 4 , which is considered as the contribution of the mineral melt, the evaporation of liquid, such as $\mathrm{V}_{2} \mathrm{O}_{5}$ with low melting temperature ( $T_{\text {Met. }}=670{ }^{\circ} \mathrm{C}=943 \mathrm{~K}[31]$ ) and $\mathrm{V}_{2} \mathrm{O}_{5}-\mathrm{Fe}_{2} \mathrm{O}_{3}$ binary system (mol fraction of $\mathrm{Fe}_{2} \mathrm{O}_{3}<0.5$ ) with low liquidus temperature [32], and the decomposition of high valent manganese oxide (such as $\mathrm{MnO}_{2}$ ) with the following Reaction (9) [31,34,35].

$$
\begin{gathered}
4 \mathrm{MnO}_{2}(\mathrm{~s})=2 \mathrm{Mn}_{2} \mathrm{O}_{3}(\mathrm{~s})+\mathrm{O}_{2}(\mathrm{~g}) \\
T_{\text {Dec. }}=460^{\circ} \mathrm{C}, T_{\text {Boi. }}=550{ }^{\circ} \mathrm{C} ; \\
\Delta G_{\mathrm{r}}^{\circ}=-74.028 \mathrm{~kJ} / \mathrm{mol}, \Delta G^{\circ}=-75.890 \mathrm{~kJ} / \mathrm{mol} \text { at } 1100 \mathrm{~K}(\text { Extrapolated data); } \\
\Delta H^{\circ}{ }_{\mathrm{r}}=149.026 \mathrm{~kJ} / \mathrm{mol}, \Delta H^{\circ}{ }_{\mathrm{r}}=166.00 \mathrm{~kJ} / \mathrm{mol} \text { at } 1100 \mathrm{~K} \text { (Extrapolated data) }
\end{gathered}
$$

\subsection{Vanadium Loss and Vanadium Leaching Efficiency}

As the abovementioned analyses, roasting temperature is important for the interaction reactions among the compounds in the ore and transformation process in roasting is significant for the vanadium leaching efficiency in the subsequent leaching process. In order to clear the transformation of vanadium-bearing titanomagnetite concentrate in the roasting, the experimental conditions in this study are set at $800{ }^{\circ} \mathrm{C}, 900{ }^{\circ} \mathrm{C}, 1000{ }^{\circ} \mathrm{C}, 1100{ }^{\circ} \mathrm{C}, 1200{ }^{\circ} \mathrm{C}$, or $1250{ }^{\circ} \mathrm{C}$ of roasting temperature respectively, $2 \mathrm{~h}$ of roasting time, $-74 \mu \mathrm{m}$ of particle size, $250{ }^{\circ} \mathrm{C}$ of leaching temperature with high pressure of $1.3 \mathrm{MPa}, 4 \mathrm{~h}$ of leaching time, 3:1 of the ratio of liquor to solid, and $100 \mathrm{~g} / \mathrm{L} \mathrm{NaOH}$ as leaching agent.

Vanadium compounds will evaporate at elevated temperature and this will cause a loss of vanadium, mass change $-1.8 \%$, as shown in Figure 4 and reduce the recovery ratio of vanadium. Therefore, vanadium loss defined as Formula (10) is related to roasting temperature.

$$
\eta=\left(1-\frac{m_{2} \beta}{m_{1} \alpha}\right) \times 100 \%
$$

where $\eta$-vanadium loss, $\% ; m_{1}$-mass of the sample before roasting, $g ; m_{2}$-mass of the sample after roasting, $g$; $\alpha$-vanadium content in the sample before roasting, $\% ; \beta$-vanadium content in the sample after roasting, $\%$.

The detail data on masses and vanadium contents of the samples before and after roasting for calculating vanadium loss are shown in Table 2. Figure 5 shows the relationship of vanadium loss with roasting temperature. As shown in Figure 5, vanadium loss is not high and lower than 20\% in general. Vanadium loss increases with the increase of temperature because the evaporation of vanadium compounds at elevated temperature is high. The trend of increase of vanadium loss is obvious when roasting temperature is higher than $100{ }^{\circ} \mathrm{C}$, which is in agreement with the TG-DSC analysis. Therefore, roasting of the ore is necessary and low roasting temperature is required for reducing vanadium loss to satisfy the high demand.

Leaching efficiency was introduced as an index for evaluating the roasting and leaching processes and defined as Formula (11), which indicates that higher conversion ratio of V(III) into V(V) leads to higher vanadium leaching efficiency and vice versa when leaching conditions are same.

$$
\gamma=\left(1-\frac{m_{4} \varphi}{m_{3} \psi}\right) \times 100 \%
$$


where $\gamma$-vanadium leaching efficiency, $\% ; m_{3}$-mass of sample before leaching, $g ; m_{4}$-mass of residue after leaching, g; $\psi$-vanadium content in the sample before leaching, \%; $\varphi$-vanadium content of residue after leaching, \%.

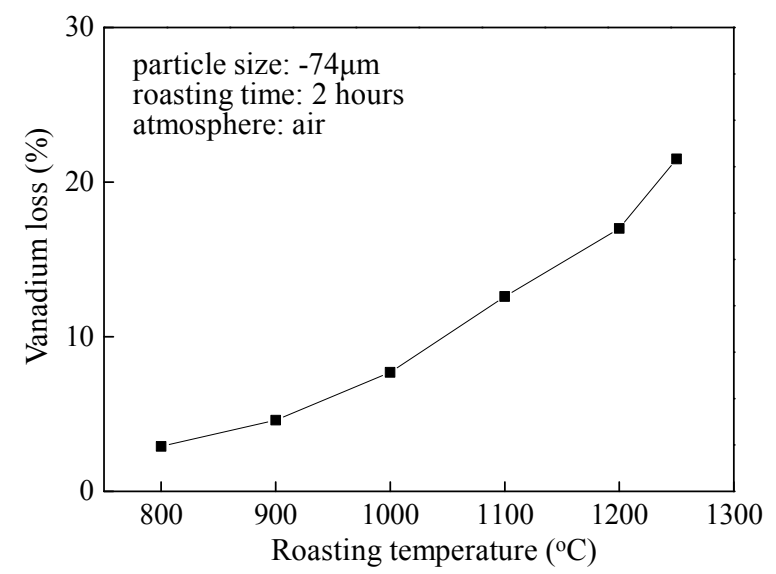

Figure 5. Effect of roasting temperature on vanadium loss.

Table 2. Masses and vanadium contents of the samples before and after roasting and vanadium loss. Roasting time: $2 \mathrm{~h}$, particle size: $-74 \mu \mathrm{m}$ of particle size, atmosphere: air.

\begin{tabular}{cccccc}
\hline $\boldsymbol{T}_{\text {roa. }}\left({ }^{\circ} \mathbf{C}\right)$ & $\boldsymbol{m}_{\mathbf{1}}(\mathbf{g})$ & $\boldsymbol{\alpha} \mathbf{( \% )}$ & $\boldsymbol{m}_{\mathbf{2}} \mathbf{( g )}$ & $\boldsymbol{\beta} \mathbf{( \% )}$ & $\eta \mathbf{( \% )}$ \\
\hline 800 & 75.14 & 0.414 & 75.89 & 0.398 & 2.9 \\
900 & 75.36 & 0.414 & 76.88 & 0.387 & 4.6 \\
1000 & 75.10 & 0.414 & 75.89 & 0.378 & 7.7 \\
1100 & 75.21 & 0.414 & 74.18 & 0.367 & 12.6 \\
1200 & 75.16 & 0.414 & 73.16 & 0.353 & 17.0 \\
1250 & 75.25 & 0.414 & 72.17 & 0.339 & 21.5 \\
\hline
\end{tabular}

The detail data on masses and vanadium contents of the samples before and after leaching for calculating vanadium leaching efficiency are shown in Table 3. Figure 6 shows the relationship of vanadium leaching efficiency with roasting temperature. As shown in Figure 6, vanadium leaching efficiency increases with the increase of temperature, when roasting temperature is lower than $1200{ }^{\circ} \mathrm{C}$. This indicates that conversion ratio of $\mathrm{V}(\mathrm{III})$ into $\mathrm{V}(\mathrm{V})$ increases with the increase of temperature when the roasting temperature is lower than $120{ }^{\circ} \mathrm{C}$. The vanadium leaching efficiency is $59.1 \%$ at $1200{ }^{\circ} \mathrm{C}$ for $2 \mathrm{~h}$ under the air atmosphere (particle size: $-74 \mu \mathrm{m}$ ) and it indicates that the novel process is feasible. However, the vanadium leaching efficiency decreases when the roasting temperature is above $1200{ }^{\circ} \mathrm{C}$. The reason for the reduction in leaching efficiency at $1250{ }^{\circ} \mathrm{C}$ of roasting temperature will be discussed by XRD and SEM-EDS analyses at subsequent discussion on transformation of vanadium-bearing titanomagnetite in roasting.

Table 3. Masses and vanadium contents of the samples before and after leaching and vanadium leaching efficiency. Leaching temperature: $250^{\circ} \mathrm{C}$, pressure: $1.3 \mathrm{MPa}$, leaching time: $4 \mathrm{~h}$, the ratio of liquor to solid: 3:1, leaching agent: $100 \mathrm{~g} / \mathrm{L} \mathrm{NaOH}$.

\begin{tabular}{cccccc}
\hline $\boldsymbol{T}_{\text {roa. }}\left({ }^{\circ} \mathbf{C}\right)$ & $\boldsymbol{m}_{\mathbf{3}}(\mathbf{g})$ & $\boldsymbol{\psi} \mathbf{( \% )}$ & $\boldsymbol{m}_{\mathbf{4}} \mathbf{( g )}$ & $\boldsymbol{\varphi} \mathbf{( \% )}$ & $\gamma(\mathbf{\%})$ \\
\hline 800 & 150 & 0.395 & 147.803 & 0.272 & 32.1 \\
900 & 150 & 0.387 & 147.207 & 0.249 & 36.9 \\
1000 & 150 & 0.375 & 147.113 & 0.209 & 45.3 \\
1100 & 150 & 0.361 & 146.562 & 0.186 & 49.7 \\
1200 & 150 & 0.355 & 146.121 & 0.149 & 59.1 \\
1250 & 150 & 0.337 & 146.891 & 0.148 & 57.0 \\
\hline
\end{tabular}




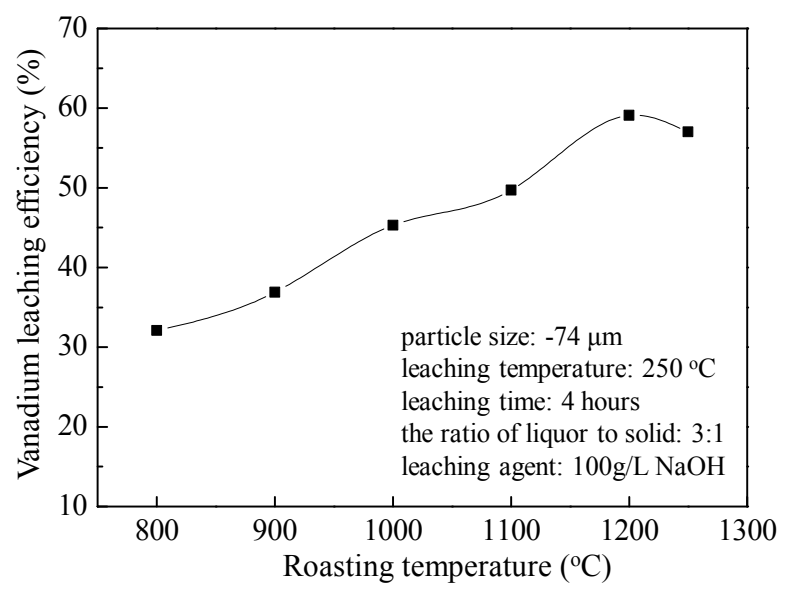

Figure 6. Effect of roasting temperature on vanadium leaching efficiency.

\subsection{Transformation Reactions Analyses in Roasting}

In order to clear the transformation reactions, the samples before and after roasting were analyzed by XRD, as shown in Figure $7 . \mathrm{Fe}_{2} \mathrm{O}_{3}$ and $\mathrm{Fe}_{2} \mathrm{TiO}_{5}\left(\mathrm{Fe}_{2} \mathrm{O}_{3} \cdot \mathrm{TiO}_{2}\right)$ were detected in the samples after roasting, which is attributed that $\mathrm{Fe}_{3} \mathrm{O}_{4}$ and $\mathrm{FeTiO}_{3}\left(\mathrm{FeO} \cdot \mathrm{TiO}_{2}\right)$ were oxidized respectively in the atmosphere as shown by the Reactions (3) and (8) [31] in Figure 1. Figure 7 shows that there was a little $\mathrm{Fe}_{3} \mathrm{O}_{4}$ in the sample due to its inadequate oxidation at $800{ }^{\circ} \mathrm{C}$ (Figure $7 \mathrm{~b}$ ), but all of $\mathrm{Fe}$ (II) were oxidized into $\mathrm{Fe}(\mathrm{III})\left(\mathrm{Fe}_{2} \mathrm{O}_{3}\right)$ at $1000{ }^{\circ} \mathrm{C}$ or higher temperature (Figure $7 \mathrm{c}-\mathrm{e}$ ). Furthermore, it is found that there was no vanadium oxide in Figure 7 because the amounts of vanadium oxides, usually considered as the form of $\mathrm{FeO} \cdot \mathrm{V}_{2} \mathrm{O}_{3}$, in the ores are small $(<0.8 \%)$. However, the oxidizations of $\mathrm{V}_{2} \mathrm{O}_{3}$ (Reaction (12) [31]) and $\mathrm{FeO} \cdot \mathrm{V}_{2} \mathrm{O}_{3}$ (Reaction (13) [31]) is easier than that of $\mathrm{Fe}_{3} \mathrm{O}_{4}$ (Reaction (14) [31]) based on thermodynamic analysis (shown in Figure 1 and listed below) when the roasting temperature is higher than $1134 \mathrm{~K}$, so oxidization of $\mathrm{V}_{2} \mathrm{O}_{3}$ would happen during the roasting experiment if there were $\mathrm{Fe}_{2} \mathrm{O}_{3}$ in the ore, i.e., Reactions (12) and (13) [31] would happen in the roasting, although the related compounds $\left(\mathrm{V}_{2} \mathrm{O}_{5}\right)$ were not found in Figure 7.

$$
\begin{gathered}
\mathrm{V}_{2} \mathrm{O}_{3}(\mathrm{~s})+\mathrm{O}_{2}(\mathrm{~g})=\mathrm{V}_{2} \mathrm{O}_{5}(\mathrm{l}) \\
\Delta G^{\circ}{ }_{\mathrm{r}}=-137.521 \mathrm{~kJ} / \mathrm{mol} \mathrm{O}_{2} \text { at } 1300 \mathrm{~K}
\end{gathered}
$$

$$
\begin{gathered}
2 / 3 \mathrm{FeO} \cdot \mathrm{V}_{2} \mathrm{O}_{3}(\mathrm{~s})+2 / 3 \mathrm{FeO}(\mathrm{s})+\mathrm{O}_{2}(\mathrm{~g})=2 / 3 \mathrm{Fe}_{2} \mathrm{O}_{3}(\mathrm{~s})+2 / 3 \mathrm{~V}_{2} \mathrm{O}_{5}(\mathrm{l}) \\
\Delta \mathrm{G}^{\circ} \mathrm{r}=-156.521 \mathrm{~kJ} / \mathrm{mol} \mathrm{O}_{2} \text { at } 1300 \mathrm{~K}
\end{gathered}
$$

$$
\begin{gathered}
4 \mathrm{Fe}_{3} \mathrm{O}_{4}(\mathrm{~s})+\mathrm{O}_{2}(\mathrm{~g})=6 \mathrm{Fe}_{2} \mathrm{O}_{3}(\mathrm{~s}) \\
\Delta G^{\circ}{ }_{\mathrm{r}}=-108.968 \mathrm{~kJ} / \mathrm{mol} \mathrm{O} \mathrm{O}_{2} \text { at } 1300 \mathrm{~K}
\end{gathered}
$$

The samples before and after roasting were subjected to SEM-EDS analysis. Figure 8 shows microphotographs of the samples before and after experiments at different roasting temperatures. As shown in Figure 8a,b, there were no obvious changes for the samples before and after experiments at $800{ }^{\circ} \mathrm{C}$. However, some solids react at low temperature, according to Reactions (3)-(8) [31,32] as evident from Figure 1, and crystal bridges, which can connect the neighboring particles with different compositions together, are generated between the solid compositions at lower temperature. Melting on the surface of particles happened when roasting temperature is higher than $1000{ }^{\circ} \mathrm{C}$ (Figure $8 \mathrm{c}, \mathrm{d}$ ), which is endothermic and agrees with the results of TG-DSC (Figure 4). Figure 8d shows that melting of the ore particle was more obvious and ore particles become bigger at $1200{ }^{\circ} \mathrm{C}$ than those in Figure $8 \mathrm{c}$ at $1000{ }^{\circ} \mathrm{C}$. The melting on the surface is considered that compounds with low melting temperature, such as vanadium pentaoxide $\left(\mathrm{V}_{2} \mathrm{O}_{5}, T_{\mathrm{Mel}}=670{ }^{\circ} \mathrm{C}[31,32]\right)$, iron cordierite $\left(\mathrm{Fe}_{2} \mathrm{Al}_{4} \mathrm{Si}_{5} \mathrm{O}_{18}, T_{\mathrm{Mel}}=1083{ }^{\circ} \mathrm{C}\right.$ [32] $)$ and fayalite $\left(\mathrm{Fe}_{2} \mathrm{SiO}_{4}, T_{\text {Mel. }}=120{ }^{\circ} \mathrm{C}\right.$ [32] $)$, were generated at low temperature as shown by Reactions (15) [31], (16) [31,32], (18) [32], and (19) [31] respectively and melt 
at elevated temperature. In addition, liquids would be generated because some chemical reactions or phase transformation reaction happened at elevated temperature as shown by Reactions $(17)[31,32]$ and (20) [32]. Furthermore, the addition of other components can decrease the liquidus temperature of mixtures to some extent. For example, the liquidus temperature of mixture of $\left(\mathrm{Fe}_{2} \mathrm{SiO}_{4}+\mathrm{Al}_{2} \mathrm{O}_{3}\right)$ with a composition near to $\mathrm{Fe}_{2} \mathrm{SiO}_{4}$ is lower than $1205^{\circ} \mathrm{C}$, the melting temperature of $\mathrm{Fe}_{2} \mathrm{SiO}_{4}$, based on the phase diagram analysis. Although there is no $\Delta G^{\circ}{ }_{r}$ data on Reaction (18) for justifying the reaction, $\mathrm{FeO}-\mathrm{SiO}_{2}-\mathrm{Al}_{2} \mathrm{O}_{3}$ ternary phase diagram [32] and Figure 9 both show that there $\mathrm{is}_{2} \mathrm{Fe}_{2} \mathrm{Al}_{4} \mathrm{Si}_{5} \mathrm{O}_{18}$ in the system, which indicates that Reaction (18) [32] would happen in the roasting. Therefore, main phases of $\mathrm{Fe}_{2} \mathrm{O}_{3}$ and $\mathrm{Fe}_{2} \mathrm{TiO}_{5}$ were connected and sintered with crystal bridges and the binding phases of the compounds with low melting temperature. In fact, the generation of the compounds with low melting temperature is beneficial to the oxidation of $\mathrm{V}(\mathrm{III})$ into $\mathrm{V}(\mathrm{V})$ because vanadium oxide and oxygen transport easily in liquid. This is also the reason that high temperature roasting is in favor of the vanadium extraction, i.e., conversion ratio of $\mathrm{V}(\mathrm{III})$ into $\mathrm{V}(\mathrm{V})$ increases with the increase of temperature which finally leads to the increase of vanadium leaching efficiency as shown in Figure 6 . Another reason why high temperature is beneficial to vanadium extraction is the decomposition of complex compounds at elevated temperature and recrystallization at low temperature, after breaking the structure of vanadium spinel.

$$
\begin{aligned}
& \mathrm{V}_{2} \mathrm{O}_{3}(\mathrm{~s})+\mathrm{O}_{2}(\mathrm{~g})=\mathrm{V}_{2} \mathrm{O}_{5}(\mathrm{~s}) \\
& \Delta G_{\mathrm{r}}^{\circ}=-178.176 \mathrm{~kJ} / \mathrm{mol} \mathrm{O}_{2} \text { at } 900 \mathrm{~K} \\
& 2 / 3 \mathrm{FeV}_{2} \mathrm{O}_{4}(\mathrm{~s})+2 / 3 \mathrm{FeO}(\mathrm{s})+\mathrm{O}_{2}(\mathrm{~g})=2 / 3 \mathrm{Fe}_{2} \mathrm{~V}_{2} \mathrm{O}_{8}(\mathrm{~s}), \mathrm{T}<1113 \mathrm{~K}\left(840^{\circ} \mathrm{C}\right) \\
& \Delta G^{\circ}{ }_{\mathrm{r}}=-215.877 \mathrm{~kJ} / \mathrm{mol} \mathrm{O}_{2} \text { at } 900 \mathrm{~K}, \Delta G^{\circ}{ }_{\mathrm{r}}=-184.979 \mathrm{~kJ} / \mathrm{mol} \mathrm{O}_{2} \text { at } 1100 \mathrm{~K} \\
& 2 / 3 \mathrm{FeV}_{2} \mathrm{O}_{4}(\mathrm{~s})+2 / 3 \mathrm{FeO}(\mathrm{s})+\mathrm{O}_{2}(\mathrm{~g})=2 / 3 \mathrm{Fe}_{2} \mathrm{O}_{3}(\mathrm{~s})+2 / 3 \mathrm{~V}_{2} \mathrm{O}_{5}(\mathrm{l}), \mathrm{T}>1113 \mathrm{~K}\left(840{ }^{\circ} \mathrm{C}\right) \\
& \Delta G^{\circ}{ }^{\circ}=-128.231 \mathrm{~kJ} / \mathrm{mol} \mathrm{O}_{2} \text { at } 1300 \mathrm{~K} \\
& \Delta G^{\circ}{ }_{r}=-6.221 \mathrm{~kJ} / \mathrm{mol} \text { at } 900 \mathrm{~K}, \Delta G^{\circ}{ }_{\mathrm{r}}=-1.044 \mathrm{~kJ} / \mathrm{mol} \text { at } 1100 \mathrm{~K}
\end{aligned}
$$

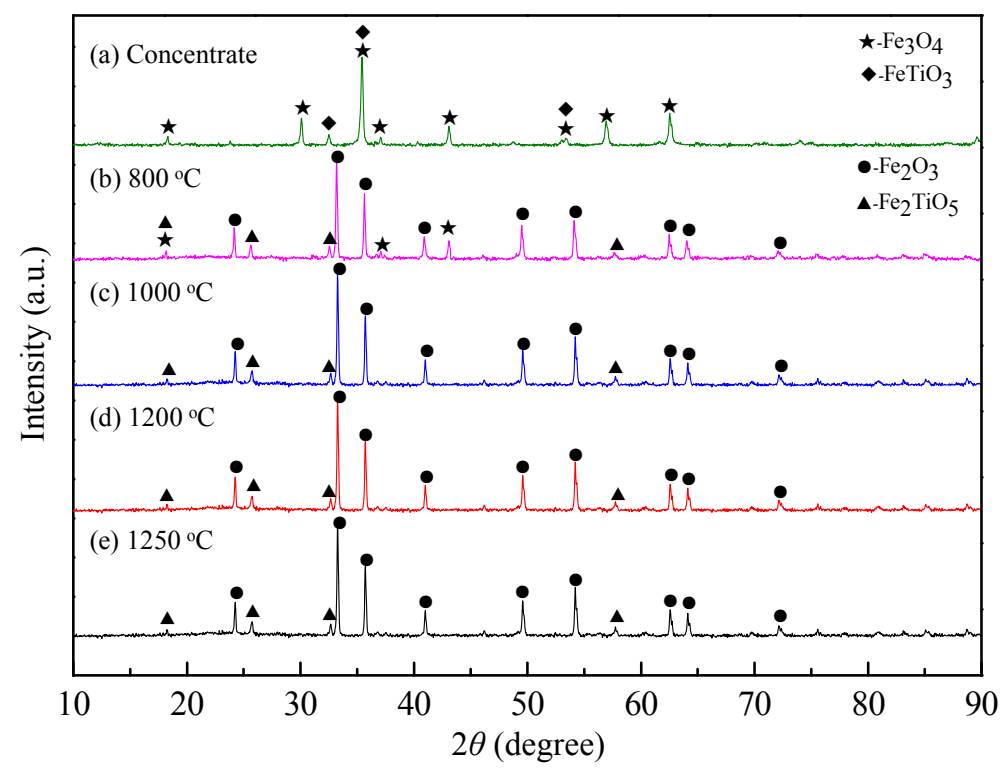

Figure 7. XRD patterns of vanadium-bearing titanomagnetite concentrate before and after roasting (roasting time: $2 \mathrm{~h}$; atmosphere: air): (a) Concentrate; (b) $800^{\circ} \mathrm{C}$; (c) $1000^{\circ} \mathrm{C}$; (d) $1200{ }^{\circ} \mathrm{C}$; (e) $1250{ }^{\circ} \mathrm{C}$. 

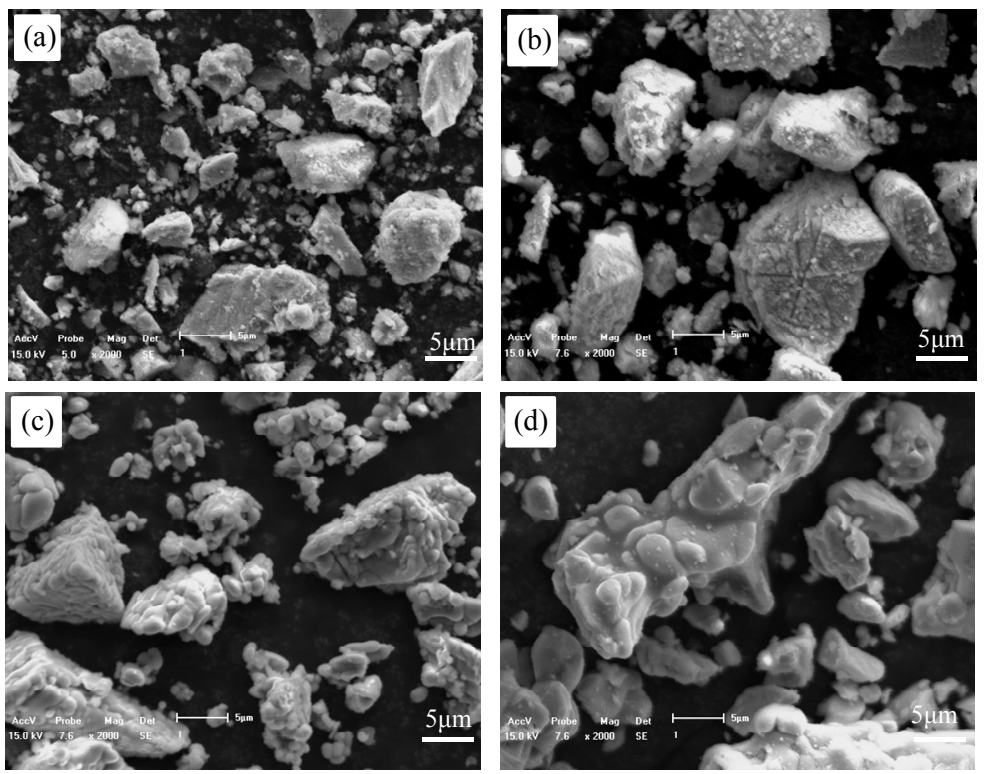

Figure 8. Changes of concentrate appearances at different roasting temperatures: (a) Raw material; (b) Sample after roasting at $800{ }^{\circ} \mathrm{C}$; (c) Sample after roasting at $1000{ }^{\circ} \mathrm{C}$; (d) Sample after roasting at $1200{ }^{\circ} \mathrm{C}$.
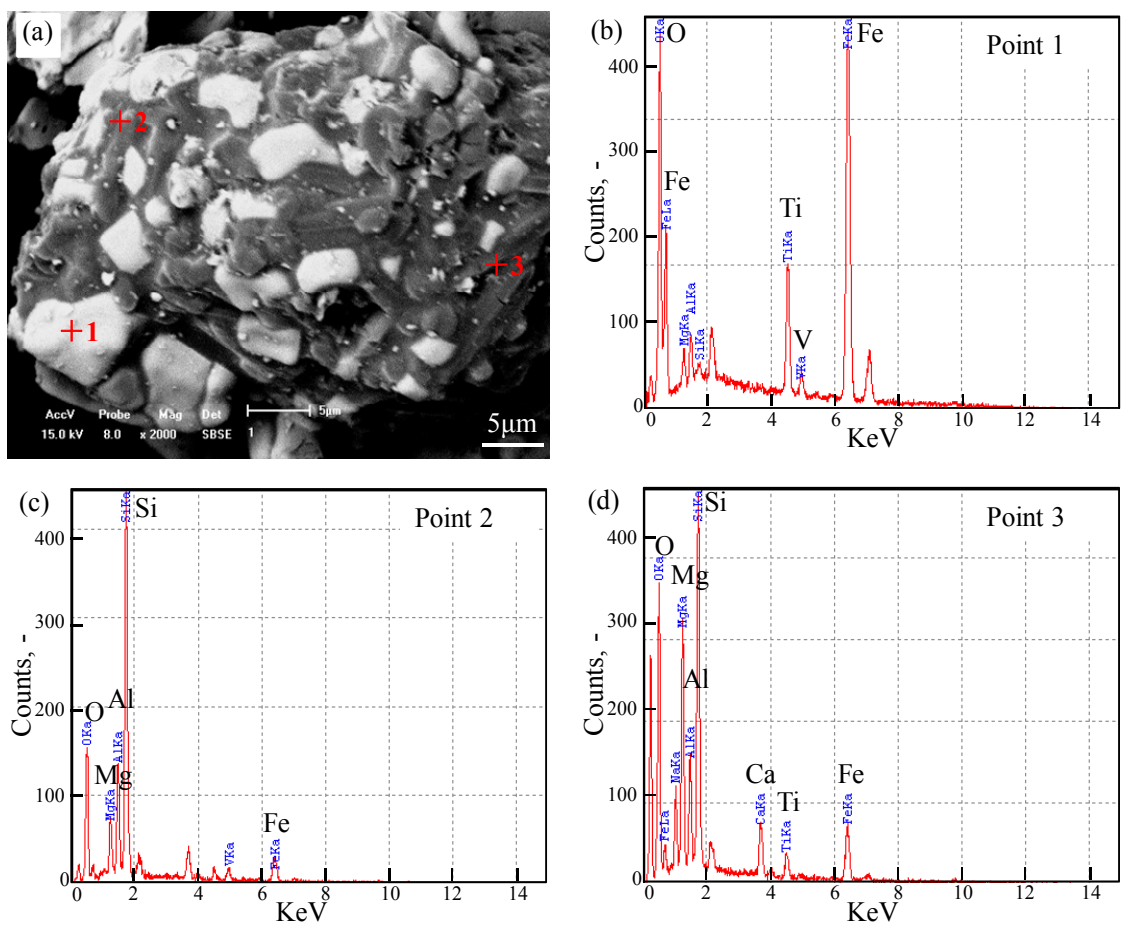

Figure 9. SEM micrograph and EDS of the roasted product at $1250^{\circ} \mathrm{C}:(\mathbf{a})$ SEM micrograph; (b) EDS of Point 1 in Figure 9a; (c) EDS of Point 2 in Figure 9a; (d) EDS of Point 3 in Figure 9a.

It is noted that over high temperature $\left(>1200^{\circ} \mathrm{C}\right)$ can cause a decrease in the vanadium leaching efficiency as shown in Figure 6. This result can be explained using the SEM-EDS analysis of the roasted product at $1250^{\circ} \mathrm{C}$ shown in Figure 9 .

Figure 9 a shows that sinter of the ore particle is significant and there are some of white aggregations on the surface of the ore particle, which is called as over-burning. Based on the analysis of EDS (Figure 9b), the white aggregations are the complex compounds of $\mathrm{Fe}, \mathrm{Ti}, \mathrm{V}$, and $\mathrm{O}$. The particle size is larger than the original size because high temperature would accelerate the melting, aggregation, 
and sinter of silicate which causes some of the vanadium wrapped by molten silicate, called a silicate network, prevents the conversion of $\mathrm{V}(\mathrm{III})$ into $\mathrm{V}(\mathrm{V})$, and finally decreases the vanadium leaching efficiency. Figure $9 \mathrm{c}, \mathrm{d}$ indicate that the complex compounds of $\mathrm{Fe}, \mathrm{Si}, \mathrm{Mg}, \mathrm{Al}$, and $\mathrm{O}$ are generated and it agrees with the Reaction (18) and $\mathrm{FeO}-\mathrm{SiO}_{2}-\mathrm{Al}_{2} \mathrm{O}_{3}$ ternary phase diagram [32].

The schematic diagrams of transformation behavior of the samples are shown in Figure 10. Figure 10a is the schematic diagram for Figure 8a in which the outline of the samples before roasting is straight and sharp. Figure 10b is for Figure $8 \mathrm{~b}-\mathrm{d}$ in which the crystal bridges obtained by the reactions among solid compounds and some of binding phases generated connect the neighboring particles and thus the outline become blunt. Figure 10c is the equivalent for Figure 9a.
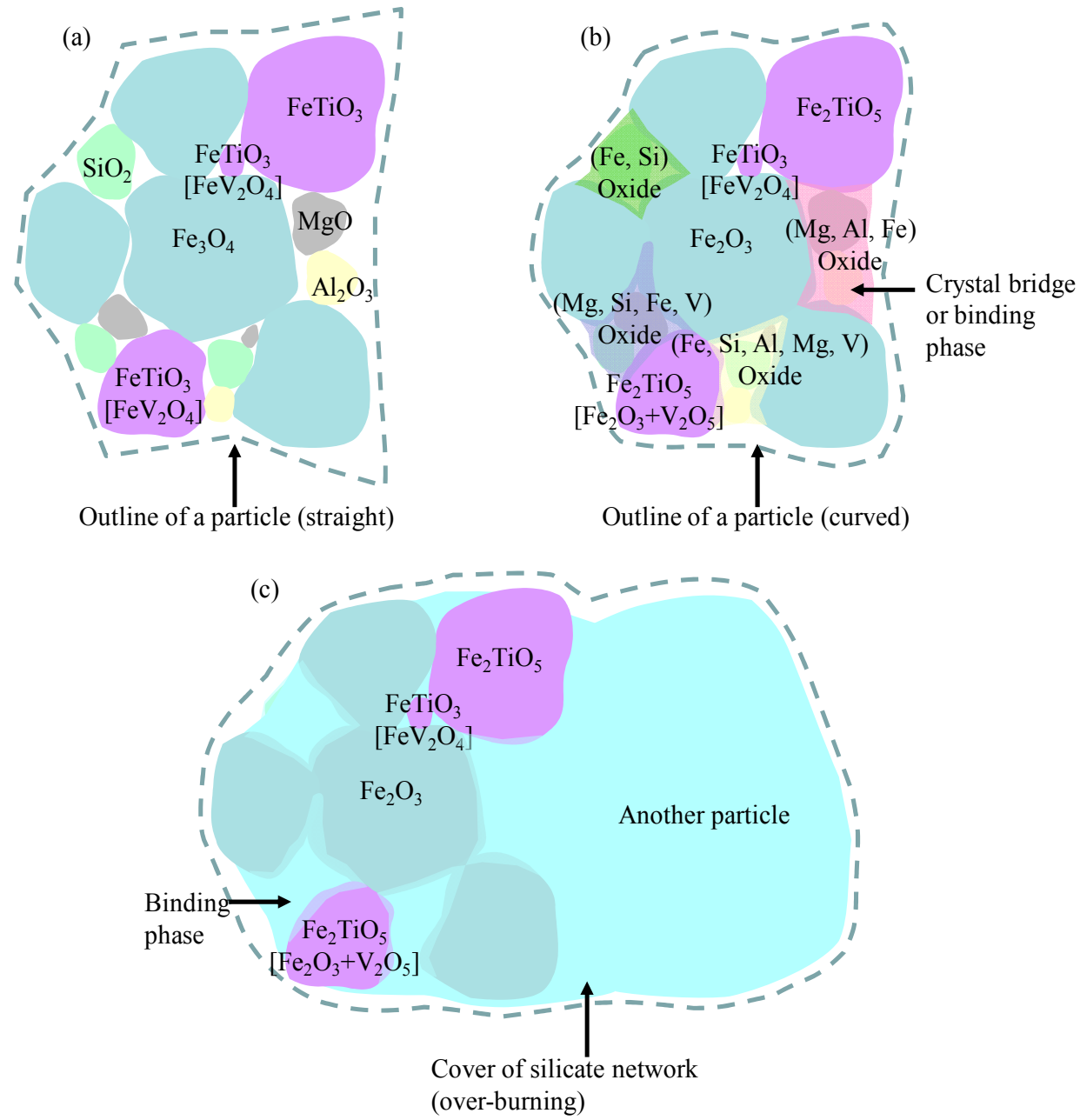

Figure 10. The schematic diagrams of phase transformation behavior of the samples: (a) A particle before roasting; (b) A particle after roasting $\left(800-1200^{\circ} \mathrm{C}\right)$; (c) Aggregation and sinter of two particles after roasting $\left(1250^{\circ} \mathrm{C}\right)$.

Based on the abovementioned analyses, the proposed process by additive-free roasting-alkaline leaching is successful. The roasting of the ore is necessary for improving the leaching efficiency and roasting at $1200{ }^{\circ} \mathrm{C}$ for $2 \mathrm{~h}$ under the air atmosphere is appropriate to minimize vanadium loss and reduce energy consumption by $3.6 \%$ compared with roasting at $1250{ }^{\circ} \mathrm{C}$ for $2 \mathrm{~h}$ (based on laboratory conditions).

\section{Conclusions}

Transformation of vanadium-bearing titanomagnetite concentrate in the roasting (over the range of $800-1250^{\circ} \mathrm{C}$ ) was discussed based on thermodynamic analyses and experimental results. Some conclusions are achieved as follows. 
- Thermodynamic analyses show that oxidation of $\mathrm{V}_{2} \mathrm{O}_{3}$ would happen in the roasting experiment over the range of $327-1327^{\circ} \mathrm{C}$ and vanadium-iron spinel phase $\left(\mathrm{FeV}_{2} \mathrm{O}_{4}\right)$ can be oxidized more easily than magnetite $\left(\mathrm{Fe}_{3} \mathrm{O}_{4}\right)$ when the temperature is higher than $861{ }^{\circ} \mathrm{C}$.

- The compounds $\left(\mathrm{V}_{2} \mathrm{O}_{5}, \mathrm{Fe}_{2} \mathrm{Al}_{4} \mathrm{Si}_{5} \mathrm{O}_{18}\right.$, and $\left.\mathrm{Fe}_{2} \mathrm{SiO}_{4}\right)$ with low melting temperature were generated at low temperature and melted at elevated temperature; liquids were generated due to some chemical reactions or phase transformation reaction $\left(\mathrm{Fe}_{2} \mathrm{~V}_{2} \mathrm{O}_{4}(\mathrm{~s}) \rightarrow \mathrm{Fe}_{2} \mathrm{O}_{3}(\mathrm{~s})+\right.$ liquid) happened at elevated temperature; main phases of $\mathrm{Fe}_{2} \mathrm{O}_{3}$ and $\mathrm{Fe}_{2} \mathrm{TiO}_{5}$ are connected and sintered with the binding phases of the compounds with low melting temperature or the mixtures with low liquidus temperature.

- Higher roasting temperature is beneficial for improving the vanadium leaching efficiency. However, over-burning causes some vanadium oxide wrapped by silicate network and reductions in the vanadium leaching efficiency from $59.1 \%$ at $T_{\text {roa. }}=1200{ }^{\circ} \mathrm{C}$ to $57 \%$ at $T_{\text {roa. }}=1250{ }^{\circ} \mathrm{C}\left(250{ }^{\circ} \mathrm{C}\right.$ of leaching temperature with high pressure of $1.3 \mathrm{MPa}, 4 \mathrm{~h}$ of leaching time, 3:1 of the ratio of liquor to solid, and $100 \mathrm{~g} / \mathrm{L} \mathrm{NaOH}$ as leaching agent).

Author Contributions: Conceptualization, H.Z.; methodology, investigation, and analysis, H.Z. and W.Z.; data curation Y.G.; revision, Q.G.; supervision and suggestion, F.S.

Funding: This research was funded by the National Science Foundation of China (NSFC 51774071 and NSFC 51604069) and Fundamental Research Funds for the Central Universities (N182504008).

Acknowledgments: The authors are grateful to X.J. and G.W., and X.H. in Northeastern University of China for valuable discussions and the supply of samples throughout this study.

Conflicts of Interest: The authors declare no conflict of interest.

\section{References}

1. Hilliard, H. Minerals Yearbook; United States Department of the Interior, Bureau of Mines: Washington, DC, USA, 1993; pp. 1259-1278.

2. Hilliard, H. The Materials Flow of Vanadium in the United States; Information Circular 9409; United States Department of the Interior, Bureau of Mines: Washington, DC, USA, 1994; pp. 1-20.

3. Liao, S.; Bai, T. Vanadium Metallurgy in Foreign; Metallurgical Industry Press: Beijing, China, 1985; pp. 161-222.

4. Moskalyk, R.R.; Alfantazi, A.M. Processing of vanadium: A review. Miner. Eng. 2003, 16, 793-805. [CrossRef]

5. Du, H. Principle of Blast Furnace Smelting Vanadium-Bearing Titanomagnetite; Science Press: Beijing, China, 1996; pp. 16-20.

6. Hukkanen, E.; Walden, H. The production of vanadium and steel from titanomagnetites. Int. J. Miner. Process. 1985, 15, 89-102. [CrossRef]

7. Deng, J.; Xue, X.; Liu, G. Current situation and development of comprehensive utilization of vanadium-bearing titanomagnetite at Pangang. J. Mater. Metall. 2007, 6, 83-86.

8. Zheng, H.; Sun, Y.; Lu, J.; Dong, J.; Zhang, W.; Sheng, F. Vanadium extraction from vanadium-bearing titanomagnetite by selective chlorination using chloride wastes $\left(\mathrm{FeCl}_{\mathrm{X}}\right)$. J. Cent. South Univ. 2017, 24, 311-317. [CrossRef]

9. Zwolak, I. Vanadium carcinogenic, immunotoxic and neurotoxic effects: A review of in vitro studies. Toxicol. Mech. Methods 2014, 24, 1-12.

10. Boulassel, B.; Sadeg, N.; Roussel, O.; Perrin, M.; Belhadj-Tahar, H. Fatal poisoning by vanadium. Forensic Sci. Int. 2011, 206, 79-81. [CrossRef] [PubMed]

11. Chen, H.; Xia, Q.; Wang, Y.; Pan, P.; Luo, D. The progress in production technology of vanadium pentoxide. J. Panzhihua Sci. Technol. 1996, 2, 11-13.

12. Zhang, Y.; Bao, S.; Liu, T.; Chen, T.; Huang, J. The technology of extracting vanadium from stone coal in China: History, current status and future prospects. Hydrometallurgy 2011, 109, 116-124. [CrossRef]

13. Zhao, L.; Wang, L.; Qi, T.; Chen, D.; Zhao, H.; Liu, Y. A novel method to extract iron, titanium, vanadium, and chromium from high-chromium vanadium-bearing titanomagnetite concentrates. Hydrometallurgy 2014, 149, 106-109. [CrossRef]

14. Li, M.; Du, H.; Zhang, S.; Wang, S.; Zhang, Y.; Liu, B.; Dreisinger, D.B.; Zhang, Z. Extraction of vanadium from vanadium slag via non-salt roasting and ammonium oxalate leaching. JOM 2017, 69, 1970-1975. [CrossRef] 
15. Cai, Z.; Zhang, Y.; Liu, T.; Huang, J. Vanadium extraction from refractory stone coal using novel composite additive. JOM 2015, 67, 2629-2634. [CrossRef]

16. Li, R.; Liu, T.; Zhang, Y.; Huang, J.; Xu, C. Efficient extraction of vanadium from vanadium-titanium magnetite concentrate by potassium salt roasting additives. Minerals 2018, 8, 25. [CrossRef]

17. Li, X.; Xie, B.; Wang, G.; Li, X. Oxidation process of low-grade vanadium slag in presence of $\mathrm{Na}_{2} \mathrm{CO}_{3}$. Trans. Nonferrous Met. Soc. China 2011, 21, 1860-1867. [CrossRef]

18. Takahashi, H.; Fujiwara, W.; Sun, H.; Yoshida, T.; Matsushima, Y. Extraction of vanadium from ammonia slag under near-atmospheric conditions. Metals 2018, 8, 414. [CrossRef]

19. Zhu, X.; Li, W.; Guan, X. Vanadium extraction from titano-magnetite by hydrofluoric acid. Int. J. Miner. Process. 2016, 157, 55-59. [CrossRef]

20. Xiang, J.; Huang, Q.; Lv, X.; Bai, C. Extraction of vanadium from converter slag by two-step sulfuric acid leaching process. J. Clean. Prod. 2018, 170, 1089-1101. [CrossRef]

21. Chen, D.; Zhao, H.; Hu, G.; Qi, T.; Yu, H.; Zhang, G.; Wang, L.; Wang, W. An extraction process to recover vanadium from low-grade vanadium-bearing titanomagnetite. J. Hazard. Mater. 2015, 294, 35-40. [CrossRef]

22. Ji, Y.; Shen, S.; Liu, J.; Xue, Y. Cleaner and effective process for extracting vanadium from vanadium slag by using an innovative three-phase roasting reaction. J. Clean. Prod. 2017, 149, 1068-1078. [CrossRef]

23. Li, H.; Fang, H.; Wang, K.; Zhou, W.; Yang, Z.; Yan, X.; Ge, W.; Li, Q.; Xie, B. Asynchronous extraction of vanadium and chromium from vanadium slag by stepwise sodium roasting-water leaching. Hydrometallurgy 2015, 156, 124-135. [CrossRef]

24. Li, H.; Wang, K.; Hua, W.; Yang, Z.; Zhou, W.; Xie, B. Selective leaching of vanadium in calcification-roasted vanadium slag by ammonium carbonate. Hydrometallurgy 2016, 160, 18-25. [CrossRef]

25. Zhang, Y.; Zhang, T.; David, D.; Lv, G.; Zhang, G.; Zhang, W.; Liu, Y. Extraction of vanadium from direct acid leach solution of converter vanadium slag. Can. Metall. Q. 2017, 56, 281-293. [CrossRef]

26. Luo, X.; Dong, H.; Zhang, S.; Liu, Y. Study on the sodium oxidation properties of low-iron vanadium-titanium magnetite with high vanadium and titanium. Energy Sources 2018, 40, 1998-2008. [CrossRef]

27. Zhang, Y.; Yi, L.; Wang, L.; Chen, D.; Wang, W.; Liu, Y.; Zhao, H.; Qi, T. A novel process for the recovery of iron, titanium, and vanadium from vanadium-bearing titanomagnetite: Sodium modification-direct reduction coupled process. Int. J. Miner. Metall. Mater. 2017, 24, 504-511. [CrossRef]

28. Bauer, G.; Volker, G.; Hans, H.; Andreas, O.; Oskar, R.; Heinz, R.; Siegfried, S. Vanadium and vanadium compounds. In Ullmann's Encyclopedia of Industrial Chemistry; Wiley-VCH: Weinheim, Germany, 2005; Volume A27, pp. 367-386.

29. Jena, B.C.; Dresler, W.; Reilly, I.G. Extraction of titanium, vanadium and iron from titanomagnetite deposits at pipestone lake, Manitoba, Canada. Miner. Eng. 1995, 8, 159-168. [CrossRef]

30. Chen, J. Handbook of Hydrometallurgy; Metallurgical Industry Press: Beijing, China, 2005; pp. 935-966.

31. Barin, I. Thermochemical Data of Pure Substances, 3rd ed.; Wiley-VCH GmbH: Weinheim, Germany, 1995; pp. 700, 702, 703, 713, 714, 716, 1047, 1505, 1692, 1778, 1780.

32. ACerS-NIST Phase Equilibria Diagrams (PC Database Ver. 4.0, NIST Standard Reference Database 31); Figures No. 96-1, 696-A; American Ceramic Society: Westerville, OH, USA; National Institute of Standards and Technology: Gaithersburg, MD, USA, 2014.

33. Chen, $\mathrm{H}$. Study on extraction of $\mathrm{V}_{2} \mathrm{O}_{5}$ from vanadium-bearing slag by lime roasting. Iron Steel Vanadium Titan. 1992, 6, 1-9.

34. Wang, X. Ferrous Metallurgy; Metallurgical Industry Press: Beijing, China, 2014; Volume 1, p. 45.

35. Huang, X. Principle of Iron and Steel Metallurgy; Metallurgical Industry Press: Beijing, China, 2017; p. 633.

(C) 2019 by the authors. Licensee MDPI, Basel, Switzerland. This article is an open access article distributed under the terms and conditions of the Creative Commons Attribution (CC BY) license (http:// creativecommons.org/licenses/by/4.0/). 